\title{
COMPARISON OF GRAIN FEED QUALITY OF DIFFERENT BROAD BEAN GENOTYPES
}

\author{
Beyza Ciftci $^{1}$, Yusuf Murat Kardes ${ }^{2}$, Kagan Kokten $^{3}$, Mahmut Kaplan $^{1 *}$ \\ ${ }^{1}$ Department of Field Crops, Faculty of Agriculture, University of Erciyes, Kayseri, Turkey \\ ${ }^{2}$ Department of Field Crops, Faculty of Agriculture, University of Bilecik Seyh Edebali, Bilecik, Turkey \\ ${ }^{3}$ Department of Field Crops, Faculty of Agriculture, University of Bingol, Bingol, Turkey
}

\begin{abstract}
The objective of the present study was to determine grain feed quality of different broad bean cultivars and lines. For this purpose, Eleven different cultivars and five lines (Emiralem, Histal, Sorgun, Kitik 2003, Sakiz, Eresen 87, Sevil, Reina Mora, Filiz 99, Salkim, Luz De, Otonoto, Seher, EU 4446, Canakkale, Antalya, EU319) were used as the plant material. Experiments were conducted in randomized blocks design with three replications. Effects of genotypes on grain feed quality were found to be highly significant $(P \leq 0.01)$

Current findings revealed that crude oil content between $0.62-1.58 \%$, crude ash content between $1.89-3.30 \%$, crude protein content varied between 22.30 - 32.14\%, acid detergent fiber (ADF) content between $7.45-14.94 \%$ and neutral detergent fiber (NDF) content between 16.08 - 28.05\%. Seher, EU 4446, Canakkale, Antalya, Filiz, 99 and Histal were found to be prominent for hight crude protein and crude oil, thus these genotypes were recommended for animal feeding.
\end{abstract}

Key words: broad bean, genotype, crude protein, $A D F, N D F$

\section{INTRODUCTION}

Legumes are used for livestock most of the time in feed rations because of high protein, energy, mineral and vitamin content of kernels (Lalles, 1993). They usually used in ruminant feed rations since ruminants are able to convert nitrogenous materials not existing in kernel proteins into microbial proteins (Christodouloua et al. 2005).

Broad bean can be used herbage, hay and grain for feeding to ruminants and green pod and grain for human nutrition (Peksen et al. 2006; Canbolat and Bayram, 2007). Broad bean is one of the oldest cultivated plants in Turkey (Karadavut et al. 2010). Broad bean grains are rich source of proteins, essential fatty acids, carbohydrates, fiber, minerals, and bioactive compounds (Canbolat and Bayram, 2007; Revilla, 2015). Researchers mostly focus on chemical composition of the feeds including the parameters of crude protein, crude ash, ADF, NDF and mineral contents (Kaplan et al. 2016). Broad bean cultivars exhibit a great variation in yield and quality traits (Micek et al. 2015; Kokten et al. 2021). 
Objective of the present study was to determine the grain quality parameters of broad bean cultivars and lines as a quality feed source for livestock.

\section{MATERIALS AND METHODS}

A total of 16 different broad bean cultivars and lines (Emiralem, Histal, Sorgun, Kitik 2003, Sakiz, Eresen 87, Sevil, Reina Mora, Filiz 99, Salkim, Luz De Otonoto, Seher, EU 4446, Canakkale, Antalya, EU319) were used as the plant material of the study. All broad bean grain was obtained from Bingol University. Broad bean grain was dried in an oven at $70{ }^{\circ} \mathrm{C}$ at 48 hours. Broad bean samples were milled through $1 \mathrm{~mm}$ sieve and used for chemical analysis. Crude ash content of samples was determined by burning at $550{ }^{\circ} \mathrm{C}$ for 8 hours. Kjeldahl method was used to determine the nitrogen $(\mathrm{N})$ content of dried broad bean samples (Buchi Kjel Master K-375). Crude protein was calculated by using the equation of Nx6.25 (AOAC 1990). NDF in accordance with Van Soest and Wine (1967) and ADF in accordance with Van Soest (1963) by using ANKOM 200 Fiber Analyzer (ANKOM Technology Corp. Fairport, NY, USA).

Analyses results were subjected to variance analysis with SAS (SAS Inst., 1999) software. Differences between mean values were tested by Duncan's multiple range test.

\section{RESULTS AND DISCUSSIONS}

Chemical composition of broad bean cultivars and lines grain are provided in Table 1 . The difference between broad bean cultivars and lines with regard to chemical composition were found to be significant at $1 \%$ level for genotypes. Crude oil of broad bean genotypes varied between 0.62 $1.58 \%$. While the lowest crude oil was obtained from Salkım cultivar, the highest value was observed in EU319 genotype. While the lowest crude ash was obtained from Sak1z cultivar $(1.89 \%)$, the highest value was observed in Salk1m cultivar $(3.30 \%)$. The lowest crude protein content was observed in Luz de Otonoto cultivar with $22.30 \%$. The highest crude protein content was seen in Histal with $32.14 \%$. The ADF and NDF contents varied between $7.45-14.94 \%$ and 16.08 - 28.05\% respectively. The lowest ADF and NDF content were obtained from Çanakkale genotype and EU319 genotype respectively. The high ADF and NDF content were obtained from Filiz 99 and Eresen 87 cultivars respectively.

Grains of broad bean is significantly affected by genotype, agricultural cultivars and climate conditions (Jasińska and Kotecki 1998; Kaplan and Kizilsimsek, 2012). Jasińska and Kotecki (1998) reported crude protein content in broad bean seed was determined more by genetic factors than by the ecological condition. High-protein grains are low-cost sources for livestock (Sadeghi et al. 2009). Tufatelli et al. (2012) reported feeding broad bean seeds in a lactation diet for cattle supports performance similar to cattle diet traditional soybean meal. Results were similar to the findings of Canbolat and Bayram (2007) and Micek et al. (2015).

Increasing $\mathrm{ADF}$ and NDF ratios reduce animal feed consumptions. It was also reported that high ADF and NDF ratios decreased digestible energy. Just because of significant effects on feed digestibility, low ADF and NDF ratios are desired in quality feeds (Bozkurt, 2011). Results were similar to the findings of Canbolat and Bayram (2007) and Micek et al. (2015).

Seed oil contents aren't stable and vary with the genetic factors ecological conditions and agricultural practices (Baydar, 2000). Seed oil is too important for energy. Crude ash is composed of unburnt portion of the dry biomass and is used as an indicator of mineral content of the feed (Gençtan, 1998). Minerals are not synthesized in animal body, so they should be supplied

http://www.natsci.upit.ro

*Corresponding author, E-mail address: mahmutkaplan5@hotmail.com 
externally. Mineral contents up to 5\% is accepted as complying with the standards, but upper limit of the minerals may vary from feed to feed (Anonymous, 2011). Results were similar to the findings of Jasińska and Kotecki (1998), Canbolat and Bayram (2007) and Micek et al. (2015).

Table 1. Chemical composition of broad bean cultivars and lines

\begin{tabular}{lccccc}
\hline \multirow{2}{*}{ Genotypes } & Crude Oil & Crude Ash & ADF & NDF & Crude protein \\
\cline { 2 - 6 } & \multicolumn{5}{c}{ (\% dry matter $)$} \\
\hline Sorgun & $1.13^{\mathrm{d}-\mathrm{g}}$ & $2.80^{\mathrm{abc}}$ & $14.42^{\mathrm{a}}$ & $19.97^{\mathrm{g}}$ & $29.66^{\mathrm{bc}}$ \\
Kitik 2003 & $1.13^{\mathrm{d}-\mathrm{g}}$ & $2.49^{\mathrm{abc}}$ & $13.58^{\mathrm{ab}}$ & $24.69^{\mathrm{bcd}}$ & $23.00^{\mathrm{gh}}$ \\
Luz de Otonoto & $0.93^{\mathrm{g}}$ & $3.19^{\mathrm{a}}$ & $7.85^{\mathrm{ef}}$ & $22.29^{\mathrm{ef}}$ & $22.30^{\mathrm{h}}$ \\
Reina Mora & $1.40^{\mathrm{abc}}$ & $2.69^{\mathrm{abc}}$ & $13.61^{\mathrm{a}}$ & $24.94^{\mathrm{bc}}$ & $28.69^{\mathrm{cd}}$ \\
Salk1m & $0.62^{\mathrm{g}}$ & $3.30^{\mathrm{a}}$ & $13.24^{\mathrm{ab}}$ & $23.88^{\mathrm{cde}}$ & $27.17^{\mathrm{de}}$ \\
Sevil & $1.23^{\mathrm{c}-\mathrm{f}}$ & $2.95^{\mathrm{ab}}$ & $11.57^{\mathrm{bc}}$ & $22.58^{\mathrm{def}}$ & $28.51^{\mathrm{cd}}$ \\
Eresen 87 & $1.37^{\mathrm{a}-\mathrm{d}}$ & $2.75^{\mathrm{abc}}$ & $13.79^{\mathrm{a}}$ & $28.05^{\mathrm{a}}$ & $24.58^{\mathrm{fg}}$ \\
Sak1z & $1.07^{\mathrm{efg}}$ & $1.89^{\mathrm{c}}$ & $13.03^{\mathrm{ab}}$ & $26.56^{\mathrm{ab}}$ & $25.94^{\mathrm{ef}}$ \\
Emiralem & $1.28^{\mathrm{b}-\mathrm{e}}$ & $2.34^{\mathrm{abc}}$ & $9.75^{\mathrm{cde}}$ & $22.01^{\mathrm{efg}}$ & $28.79^{\mathrm{cd}}$ \\
Filiz 99 & $1.28^{\mathrm{b}-\mathrm{e}}$ & $2.30^{\mathrm{abc}}$ & $14.94^{\mathrm{a}}$ & $25.67^{\mathrm{bc}}$ & $25.69^{\mathrm{ef}}$ \\
Histal & $1.02^{\mathrm{fg}}$ & $2.79^{\mathrm{abc}}$ & $8.92^{\mathrm{def}}$ & $17.69^{\mathrm{h}}$ & $32.14^{\mathrm{a}}$ \\
Çanakkale & $1.28^{\mathrm{b}-\mathrm{e}}$ & $3.29^{\mathrm{a}}$ & $7.45^{\mathrm{f}}$ & $17.35^{\mathrm{h}}$ & $31.26^{\mathrm{a}}$ \\
EU4446 & $1.05^{\mathrm{efg}}$ & $2.80^{\mathrm{abc}}$ & $9.89^{\mathrm{cd}}$ & $22.61^{\mathrm{def}}$ & $31.39^{\mathrm{ab}}$ \\
Seher & $1.52^{\mathrm{ab}}$ & $2.74^{\mathrm{abc}}$ & $9.56^{\mathrm{cde}}$ & $21.69^{\mathrm{fg}}$ & $28.52^{\mathrm{cd}}$ \\
Antalya & $1.27^{\mathrm{b}-\mathrm{f}}$ & $2.75^{\mathrm{abc}}$ & $8.94^{\mathrm{def}}$ & $17.58^{\mathrm{h}}$ & $32.06^{\mathrm{a}}$ \\
EU319 & $1.58^{\mathrm{a}}$ & $2.00^{\mathrm{bc}}$ & $9.30^{\mathrm{def}}$ & $16.08^{\mathrm{h}}$ & $31.44^{\mathrm{ab}}$ \\
\hline
\end{tabular}

\section{CONCLUSION}

Broad bean grains are a significant feed source for livestock. The broad bean genotypes investigated in present study quite well-results for ruminant. Entire genotypes can reliably be cultivated in different region for animal feeding.

\section{REFERENCES}

Anonim, (2011). “Tarım ve Köy İşleri Bakanlığg’ndan Resmi Gazete” Retrieved April 18, 2011, from “www.resmigazete.gov.tr/eskiler/2011/12/20111227-12-1.docx",

AOAC. (1990) Official Method of analysis. 15th. edn. Association of Official Analytical Chemist, Washington, DC. USA.

Bozkurt, K.A. (2011). Determination of relative feed value of some legume hays harvested at flowering stage. Asian Journal of Animal and Veterinary Advances. 6, 525-530.

Canbolat, O., Bayram G. (2007). Comparison of In Vitro gas production parameters, organic matter digestibility and metabolizable energy contents of some legume grains. Journal of Agricultural Faculty of Uludag University, 21 (1): $31-42$

Christodouloua, V., Bampidisa, V.A., Hucko, B., Ploumi, K., Iliadis, C., Robinson, P.H., Mudrik, Z. (2005). Nutritional value of chickpeas in rations of lactating ewes and growing lambs. Animal Feed Sci. Technol, 118, 229-241.

Genctan, T. (1998). Agricultural Ecology (Tarımsal Ekoloji), Trakya Üniversitesi Tekirdağ Ziraat Fakültesi, Tarla Bitkileri Bölümü, Tekirdağ, 191s.

Kaplan, M., Kızılşimşek, M. (2012). Determination of nutritional values of different grain sorghum (Sorghum bicolor L.) strains and varieties. Erciyes Üniversitesi Fen Bilimleri Enstitüsü Fen Bilimleri Dergisi, 28(1), 11-14. 


\section{Current Trends in Natural Sciences}

Vol. 10, Issue 20, pp. 39-42, 2021

https://doi.org/10.47068/ctns.2021.v10i20.005

Current Trends in Natural Sciences (on-line)

ISSN: 2284-953X

Current Trends in Natural Sciences (CD-Rom)

ISSN: 2284-9521

ISSN-L: 2284-9521

ISSN-L: 2284-9521

Kaplan, M., Üke, Ö., Kale, H., Sırac, Y., Çinar, O., Atalay, A.I. (2016). Effect of Vegetative Stages on Potential Nutritive Value, Gas Production and Methane of Teff Hay. Iğdır Üniversitesi Fen Bilimleri Enstitüsü Dergisi, 4 , 1-7.

Karadavut, U., Palta, C., Kavurmaci, Z., \& Bölek, Y. (2010). Some grain yield parameters of multi-environmental trials in faba bean (Vicia faba) genotypes. International Journal of Agriculture and Biology, 12(2), 217-220.

Kökten K., Çiftçi B., Özdemir S., Kardeş Y. M. Kaplan M. Fatty Acid Composition of The Seeds of Broad Bean (Vicia faba Var. Major L.) Genotypes From Turkey. Chemistry of Natural Compounds, 2, 1-4

Lalles, J.P. (1993). Nutritional and antinutritional aspects of soyabean and field pea proteins used in veal calf production: A review. Livestock Production Sci, 34: 181-202.

Micek, P., Kowalski, Z. M., Kulig, B., Kanski, J. (2015). Effect of variety and plant protection method on chemical composition and in vitro digestibility of faba bean (Vicia faba) seeds. Annals of Animal Science, 15(1), 143.

Pekşen, A., Pekşen, E., \& Artık, C. (2006). Determination of plant characteristics and green pod yield of some faba bean (Vicia faba L.) populations. Anadolu Tarım Bilimleri Dergisi, 21(2), 225-230.

Revilla, I. (2015). Impact of thermal processing on faba bean (Vicia faba) composition. In Processing and impact on active components in food (pp. 337-343). Academic Press.

Sadeghi, G.H., Mohammadi, L., Ibrahim, S.A., Gruber, K.J. (2009). Use of bitter vetch (Vicia ervilia) as a feed ingredient for poultry. Worlds Poult Sci J, 65, 51-64.

SAS. (1999). SAS User's Guide: Statistic. Statistical Analysis Systems Institute Inc., Cary, NC.

Tufatelli V., Khan R.U., Laudadio V. (2012). Evaluating the suitability of field beans as a substitute for soybean meal in early-lactating dairy cow: production and metabolic responses. Anim. Sci. J., 83, 136-140.

Van Soest P.J. and Wine R.H. (1967). The use of detergents in the analysis of fibrous feeds. IV. Determination of plant cell wall constituents. Journal of the Association of Official Analytical Chemists, 50, 50-55.

Van Soest, P.J. (1963). The use of detergents in the analysis of fibre feeds. II. A rapid method for the determination of fibre and lignin. Journal of the Association of Official Analytical Chemists, 46,829-835. 